\title{
Editorial: Brands and our times
}

One of the tricky issues about writing editorial features for journals, rather than now-you-see-it-now-youdon't news, is that you have no way of knowing what will be preoccupying people at the time of actual publication. You can comment generally (and certainly rather darkly at the moment) about an uncertain world situation, about wobbly economies and, of course, about the speed of change in just about everything. But post 11th September, who knows what might be the prevailing economic and social situation in early 2002?

Now clearly one of the advantages of writing about brands is that they, at least, are the most stable corporate assets. They are demonstrably the most powerful and sustainable wealth creators in the world, and certainly provide strong economic sandbags for companies - indeed nations - under pressure. ${ }^{1}$

However, we live in strange times for brands, too. Despite their economic contribution, and despite their ability to reassure on quality and consistency in a volatile world, over the last year or two they have been under more scrutiny and pressure from the media and global public opinion than ever before. Naomi Klein's book 'No Logo' has sold more than 200,000 copies in 12 languages worldwide; ${ }^{2}$ it is a nice touch of irony that the book has been at No. 1 in the Sunday Times business book bestsellers list. It has been dubbed 'the bible' of the anti-capitalist movement worldwide, and managed to reshape general protests about the globalisation of trade and business into a very specific focus on brands. Among some young audiences, it has even managed to make being anti-brand seem cool. While it was relieving and gratifying that a sophisticated and sane publication like The Economist ran a front cover and leader columns pointing out the wrongheadedness of the 'anti-brand' movement, and highlighting the broad economic and social benefits of brands, ${ }^{3}$ it has been disappointing that so many other intelligent newspapers have either been silent on these benefits or have even indulged the 'anti' arguments in a one-sided way. To add to this, particularly in the UK, so much coverage of 'brand stories' in the past year has been in the form of 'lampooning' corporate name changes and new corporate identities. Look at the press comment around examples like Consignia, Accenture and $\mathrm{mmO} 2$.

'A change of syllable from Elan to Elite ... is supposed by the McKinsey maniacs to make all the difference to volume sales'... 'if the performance of companies that have re-branded is anything to go by ... [companies] should avoid the brand consultants at all costs. ${ }^{4}$

'British companies have the dubious distinction of leading Europe in the race to adopt new identities. ${ }^{5}$

'The latest meaningless re-brand.'

Now while this coverage is about the particular case of corporate name changes, it is invariably dubbed 'rebranding' and so still contributes to the general climate in an unhelpful 
way. (It is also rather ironic that we pride ourselves on being a creative and innovative nation, and yet this kind of coverage discourages CEOs from high-profile new approaches.)

So what is really going on here, and why should brand owners and influencers mind so much about this general climate, even if it does not seem to be specifically affecting individual brands? What could be done - what needs to be done, if anything - to reframe the 'brand debate' and create the type of positive climate that brands should truly deserve? We should all mind hugely. Not just from a 'professional job' point of view but, literally, because of the health and wealth of nations.

\section{BRANDS TODAY}

Not long ago Interbrand celebrated its 25th anniversary as a company and, as part of this, the staff reminisced about how the application of the 'brand word' had changed so radically. Whereas 25 years ago brand meant boxes and bottles, packets and cans, today the term can equally as well be applied to utilities, football teams, political partners and charities. The recognition by some that charities are as much brands as many commercial organisations brings some specific ironies. When recently the author was involved in a panel debate about 'Brands: Heroes or villains', it was interesting that when asked which was her favourite brand, one of the panellists, who was speaking on behalf of the 'anti-globalisation' movement, replied 'The Red Cross'. Clearly, this brand, as with other great global charity brands like Oxfam, has delivered great economic and social advantage for their beneficiaries. Yet how often do you see these particular 'global brands' picked up in media debate?

More generally, while the ubiquity of the term 'brand' has given it extraordinary visibility, this greater visibility without proportionately greater understanding has contributed to many of today's problems. Press articles about 'rebranding Britain's three million students', Tony Blair allegedly wishing to rebrand the civil service and, most recently and ridiculously, the claim that Charlotte Beers, a senior American advertising executive, has been brought in by George W. Bush's administration to 'rebrand Osama Bin Laden', have equated rebranding with PR representation. Rebadging would be a more accurate term, and again the 'branding industry' could do much more to point out this distinction.

One perhaps more encouraging example, however, is to be found in an unlikely place, in a recent book on personal presentation. It is called 'Branding Yourself, ${ }^{7}$ and is written by Mary Spillane, the image consultant who brought the world 'Colour $\mathrm{Me}$ Beautiful'. The descriptive line on the front cover reads 'How to look, sound and believe your way to success'; an acknowledgment, in however personal a case, that branding needs to be the central organising principle, the basis for a full brand experience, if it is to be sustainably successful.

Again, the vast majority of people's understanding about brands is still tied up in the world of packaged goods with all the implications of surface design that can give. It probably also does not help when the launch of a new name and logo (usually termed a 'rebrand' by the press) is accompanied by qualitative, over-flowery descrip- 
tions of what the new name and logo is supposed to signify (eg 'the petals symbolise the coming together of our organisation' etc). Now clearly the press will report what it will, and creative descriptions can be almost irresistibly lampoonable. It is rare to see a hard and quantitative business case being reported alongside specific 'corporate makeover launches', and even more rare to see a general case being included for the extraordinary importance of branding and rebranding to the stability and energy of our economy.

It is also rare to see the cost of a 'rebranding' exercise put into perspective. All too often, the 'millions' of pounds in fees the media claim were paid to brand consultants turn out to include the cost of implementation a cost that would have had to be borne by the company anyway in reprinting stationery, replacing signage, vans etc. What is more, the cost is normally a fraction of that charged in legal and financial fees to other professional advisers.

\section{THE ECONOMIC IMPORTANCE OF BRANDS}

In the late 1980s, the intangible element ('goodwill') that made up the total market value of the FTSE 100 companies was an average of around 40 per cent. Today, it is more than 70 per cent. Now clearly not all the intangible asset value can be accounted for by brands by any means, but even an originally product- and technologybased company like IBM would say that their most important asset is their brand. Today, we can demonstrate that the brand - whether in the corporate, service, product or not-for-profit sector
— is any organisation's most important asset. In fact, it is estimated that onethird of the world's wealth can be accounted for by brands, and that is just in their commercial definition.

\section{THE SOCIAL IMPORTANCE OF BRANDS}

The fact of brands as powerful wealth creators is always going to be a problem for those who look upon the concept of wealth creation with disdain. However, it is useful to highlight their social contribution on a broader scale. On a basic level, strong brands generate customer loyalty; this leads to more security of income for the company, and so to more reliable earnings. This is reflected in more security of employment — which is itself an important social contributor. On a more emotional level, both global product and global media brands have found ways of uniting people and touching a common nerve (and, indeed, of symbolising an optimistic 'one world' view) in a way that governments have failed to do. We should always remember that brands succeed because people want them. Far from being 'bullies', they are the ultimate accountable institution; if people do not like your product, service or corporate behaviour (or cease to like it), they will stop buying you - very quickly. In this way, it is absurd to say that brands can be too powerful. Frankly, if a brand is producing a great product or service, and doing it in a way that improves people's lives and communities, why should it not grow and prosper? If these 'good' brands then become complacent, insensitive or careless, they will soon be cut down to size again by 'voting' customers and in- 
fluencers. Brands, of course, are the best incentive for companies to behave well, as it gives them a reputation to protect, wherever in the world they operate.

Whatever their motivation, any brand - any company — has to operate within the individual national culture in which it finds itself either being produced or 'sold'. The complexity of operational decisions and local working practices that this brings to some global brands does present a potentially vulnerable area, and brands like Nike and Gap have learned from the problems of having less 'on-theground control' of production. This issue of 'brand control' of, and accountability for, the production and experience chain will become an even more critical one for brands in the future, when the balance between financial, production and operational flexibility and the need for generating even greater levels of public trust must be resolved. The challenge of being clear and consistent about what a brand's vision and values are, and how these must be applied across the full brand experience and behaviour everywhere, has never been so acute.

\section{SO WHAT?}

Every brand owner and adviser will have their own particular way of expressing what it requires to build a strong brand, and this is not the place to launch into a comprehensive review and synopsis of the different approaches. However, from almost 3,000 brand studies worldwide we can summarise the core characteristics that the world's most valuable brands need both now, and looking at what will be required in the future. From some of these insights, it is also possible to see ways in which the brand climate can be enhanced for the benefit of all.

Great brands need to show clarity, consistency and leadership. That is clarity of vision, purpose and values, and consistency in the way these are applied, wherever in the world, through whatever channel and whatever category the brand extends into (this is not the same as predictability, and having to be the same everywhere). But in many ways leadership will be the most important of these characteristics in the future; in all the studies it is the most discriminating factor in driving longterm brand value.

What do we mean by leadership? Certainly we do not mean just 'brand leadership', since this is rather oldfashioned, category-based speak. It does, however, mean trying to be a brand that 'sets the agenda' and shapes markets. Certainly, at the most basic level, this has to be about leading and exceeding people's expectations at the level of product, service and creative quality.

Increasingly, though, 'leader' brands need to show this leadership at the level of values and social contribution. Brands with clear and strong values are able to transcend and leap categories. While Virgin struggles to make economic value from its brand, there is no doubting its power in people's minds; their clarity of 'championing' vision and values has allowed them to leap to categories where they have little or no product competencies. Equally FCUK has more recently used its new strength of brand to do the same. One of the fascinating things about trends in the brand world at the moment is its blurring, fragmen- 
tation and the rise of 'life' brands. A luxury fashion brand like Versace is now also a hotel and hospitality brand; a classic product brand like Lynx has developed a fuller service and retail experience in the form of a Lynx barber shop; and an established manufacturer/product brand company like Unilever has tested service brands (eg via the new 'My Home' offer) out of Persil and Cif. No brand is sacred in its market-place any more. Leader brands know that, and will act first to take more 'share of person' than share of shelf in a complex world that people need to simplify.

Showing leadership at the level of values and social contribution does not just mean spilling a bit of money into cause-related marketing. It should mean treating people who work within and for the business well, and standing for something that allows these people to engage their personal and professional energies. Also, since brands are built on relationships, it would be as well for 'leader' brands to use more personal language in their dealings, which encourages relationship building with all their audiences; all too often at the moment, companies still talk the language of 'marketing warfare', and targets and campaigns.

The final element to leadership is really to do with where this editorial started: about taking more responsibility for explaining and championing the positive wider role of brands from people within companies, to contributing to the success of business, to the wider social and economic benefits to society as a whole. Good brands do have the power to make a positive contribution to people's lives individually, and indeed to the world at large. Brand owners and influencers should not be cynical or embarrassed about this; it is not a fanciful notion but a demonstrable fact.

We all need licences to operate and licence to innovate and, indeed, more than licence; brands need supporting and encouraging government policies to thrive for the benefit of all. Political and media prejudices about 'fat cats', 'Rip-off Britain' and so on hardly reflect the kind of supportive attitude that businesses would wish for.

In the end, of course, the future success of brands is up to the brands themselves, to the way they behave and to the people who manage them. Reputation is, after all, reality with a lag effect.

\section{Rita Clifton Chairman, Interbrand}

\section{References}

(1) Business Week (2001) 'World's most valuable brands', league table, Business Week, 6th August. Also see Interbrand (2001)

'Leveraging Brand Value in a Downturn', Interbrand, February.

(2) Klein, N. (2000) 'No Logo', Flamingo (HarperCollins Publishers Ltd).

(3) The Economist (2001) "Pro Logo". Why brands are good for you', The Economist, 8 th September.

(4) The Times (2001) 12th January.

(5) Financial Times (2001) 16th January.

(6) The Guardian (2001) 17th October.

(7) Spillane, M. (2000) 'Branding Yourself, Pan Books/Macmillan UK. 
